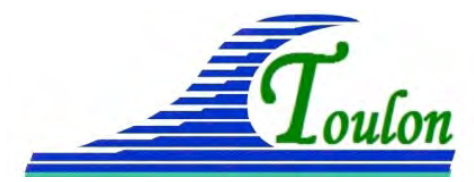

XIV èmes Journées Nationales Génie Côtier - Génie Civil Toulon, 29 juin au $1^{\text {er }}$ juillet 2016

DOI:10.5150/jngcgc.2016.058 C Editions Paralia CFL

disponible en ligne - http://www.paralia.fr - available online

\title{
AWC, a new concept of offshore wind turbine derived from Oil \& Gas technology
}

\author{
Benjamin ROUSSE ${ }^{1}$, Olivier LANGEARD ${ }^{2}$, \\ Peter BROUGHTON ${ }^{3}$, Richard L. DAVIES ${ }^{3}$
}

\section{Océanide,}

Port de Brégaillon, BP 63, 83502 La Seyne sur Mer Cedex, France.

brousse@oceanide.net

2. Doris Engineering,

58A rue du dessous des Berges, 75013 Paris, France.

langeard.o@doriseng.com

3. Marine Engineering Energy Solutions Ltd,

England.

pbroughton@meesltd.com ; davies-r@rlde.co.uk

\begin{abstract}
:
The "AWC refers to an "Articulated Wind Column", which is a new concept for an offshore wind turbine support structure based on articulated column technology that was originally developed for the Maureen offshore oil field in the North Sea. It consists of a vertical buoyant concrete cylinder articulated at a short distance above the seabed with an articulated joint connected to a concrete gravity base.

It was studied as a means of support for an 8MW wind turbine at a 90m water depth location in the Irish Sea through the use of both numerical simulation and of basin model testing.

The present paper deals mainly with the comparison between numerical simulations and model basin test results, with a particular focus on a special device used to model the wind loads in the basin.
\end{abstract}

Keywords: Wind turbine, Offshore, Concrete, Model testing

\section{Résumé :}

AWC est l'acronyme de "Articulated Wind Column", un nouveau concept de support d'éolienne en mer basé sur la technologie de la colonne articulée du champ pétrolier de Maureen. Il consiste en un cylindre vertical de béton, de flottabilité positive, et articulé au fond par un cardan fixé sur une base gravitaire.

Il a été étudié pour supporter une turbine de $8 \mathrm{MW}$ dans une profondeur de $90 \mathrm{~m}$, en mer d'Irlande, sur la base de simulations numériques et d'essais en bassin.

La présente publication s'attachera principalement à confronter les simulations numériques aux résultats des essais en bassin, avec un focus sur la modélisation originale des efforts de vent qui a été mise en œuvre. 


\section{Thème 5 - Énergies et ressources marines}

\section{Introduction}

Marine Engineering Energy Solution Limited (MEES) and DORIS Engineering (DORIS) have jointly developed a new concept for an offshore wind turbine support structure for a range of water depths between $50 \mathrm{~m}$ to $200 \mathrm{~m}$. This type of turbine support structure is referred to as the Articulated Wind Column.

The concept is based on a well-proven Oil and Gas design by DORIS for the Maureen articulated loading column in the North Sea (Fig. 1). It consists of a concrete vertical cylinder, buoyant and free to rotate above a gravity concrete base located on the seabed.

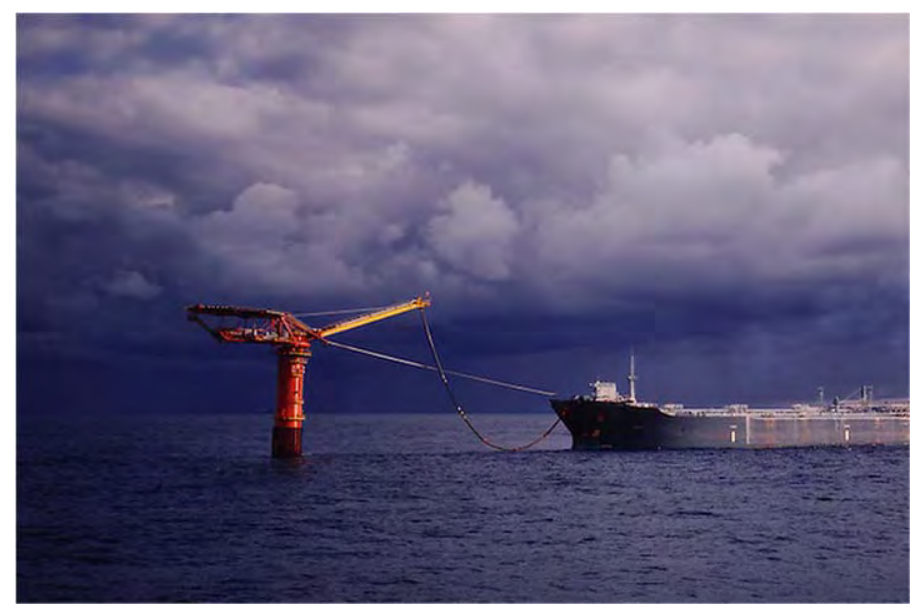

Figure 1. Maureen articulated loading column.

A Front End Engineering Design (FEED) of an AWC supporting an 8.0 MW turbine to be located in the south Irish Sea to the West of the Isle of Anglesey, within 90 metres of water has been completed. For this exercise, results from numerical computations were compared with basin tests results performed by OCEANIDE in the Basin de Génie Océanique (BGO) FIRST facility at La Seyne sur Mer (France).

The objectives of basin tests were to measure the motion behaviour of the AWC under waves, current and wind action for operating and storm conditions. The model was at 1:42.5 scale and included the base articulated joint, the column, the tower and the nacelle with the rotor, and the blades driven by an electrical motor. An innovative wind load simulator was used in order to model, with a very good accuracy, the appropriate wind load time series applied to the nacelle. Wave and current loadings were generated in the basin in order to submit the model to simultaneous wind, wave and current loads. This paper covers the description of the AWC concept, the model tests campaign and the comparison between tests results and results from numerical simulations. 


\section{XIV èmes Journées Nationales Génie Côtier - Génie Civil \\ Toulon, 29 juin au $1^{\text {er }}$ juillet 2016}

\section{AWC concept description}

The AWC concept is a wind column articulated at the base, which provides a compliant column in order to reduce forces both on the column and on the base (Fig. 2). The key advantages of the concept are:

- The low cost wind turbine substructure for water depths in the range $50 \mathrm{~m}$ to $200 \mathrm{~m}$.

- Suitability for all turbine sizes and mass production.

- Technology based on 40 years well-proven oil and gas experience.

The stability of the AWC is ensured because of the column buoyancy and its large added mass.

Sizing of the AWC was determined by the allowable motion criteria for the turbine (inclination, acceleration). Maximum operational inclinations can typically reach over 5 degrees for extremely limited periods of time. For the day-to-day case, motions are anticipated to be very limited.

The ratio of column diameter/power decreases noticeably with increasing water depth.

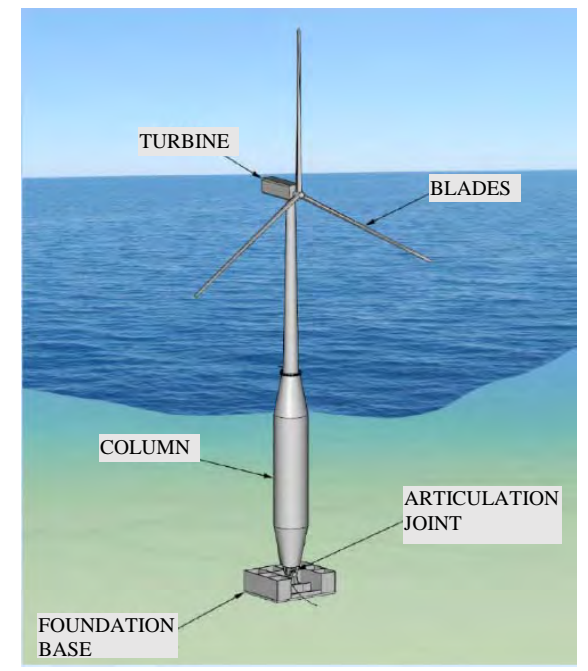

Figure 2. AWC.

The basin tests were performed in order to confirm and calibrate the numerical calculations for one particular case (8.0 MW turbine located in the Irish Sea with 90 metres water depth) and for several environmental conditions (mix of wave, current and wind, for operating, maintenance and extreme conditions). This prototype 8MW turbine tested had a blade diameter of $164 \mathrm{~m}$ and a column diameter of $17 \mathrm{~m}$. The mass of the concept without foundation (column, mast and turbine) is around $7000 \mathrm{t}$ for a buoyancy of $16000 t$.

The present paper focuses on the description of the model tests and the comparison of model test results with the numerical computations. 


\section{Thème 5 - Énergies et ressources marines}

\section{Experiments}

Basin tests were performed in the BGO FIRST. The basin (Fig. 3) is equipped with wave, current and wind generation. It is $40 \mathrm{~m}$ long, $16 \mathrm{~m}$ wide and $4.8 \mathrm{~m}$ deep. The basin floor elevation is adjustable between $0 \mathrm{~m}$ and $4.8 \mathrm{~m}$. More details on basin equipments are provided in http://www.oceanide.net.

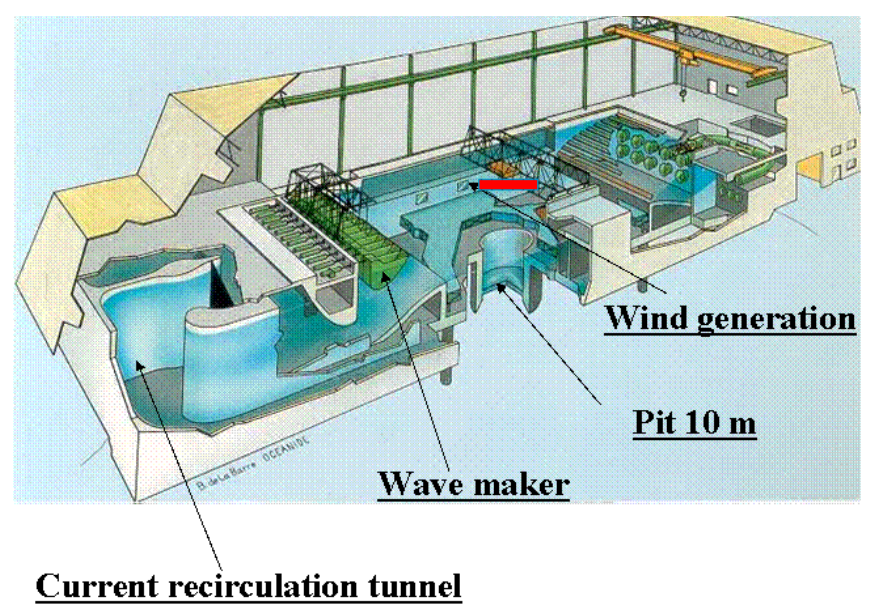

Figure 3. BGO FIRST.

The model consisted of the AWC deep water foundation, the column, the wind turbine tower, the nacelle, the rotor and the blades, each component being constructed with representative dimensions and masses. The nacelle was equipped with a DC motor in order to force the rotational speed of the rotor. The model was tested in extreme storm, operating and maintenance weather conditions, in a water depth of 90 metres. This included testing the model under wind loadings, current and wave forces (Fig. 4). Froude similitude (1:42.5 scale) was used.

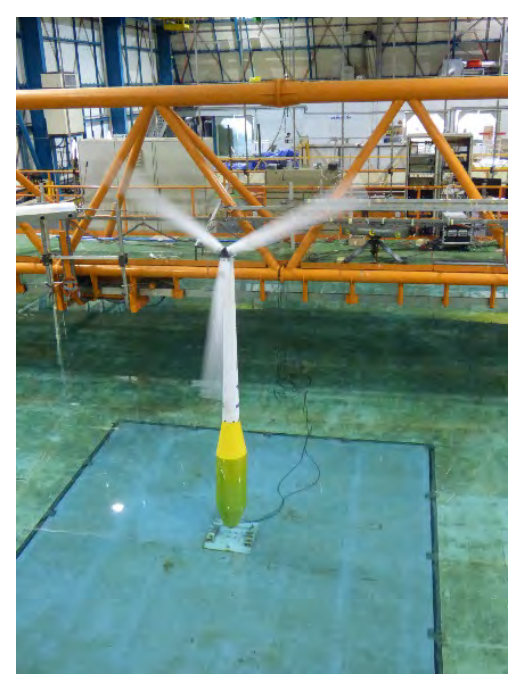

Figure 4. AWC model in the basin. 


\section{XIV èmes Journées Nationales Génie Côtier - Génie Civil \\ Toulon, 29 juin au $1^{\text {er }}$ juillet 2016}

\subsection{Wind Load Modelling}

For offshore wind turbine basin tests, one difficulty is to model in a representative way the wind load applied on the blades at the appropriate scale, mainly due to Reynolds scale effects. The blade profile should be adapted in order to compensate as far as possible the Reynolds effects. The blades inclination should be controlled dynamically, the wind speed should be constant all over the area covered by the blades and the level of turbulence of the wind should be adequately represented. These constraints should be applied to a scaled model in addition to the mass and inertia constraints. Since the first basin model tests of other offshore wind turbine concepts, including the tests performed by OCEANIDE on a TLP (Tensioned Leg Platform) concept in 2001 (MOLIN et al., 2002), a lot of different techniques (equivalent disc, modified blades profile or added roughness on blades to compensate for Reynolds' effect...) have been developed and qualified but none has given full satisfaction.

In order to find a way around those difficulties and to increase the accuracy of the wind modelling for wind turbine applications, an innovative wind load simulator has been developed by OCEANIDE. The concept consists of using the wind load time series from calculations at prototype scale (from DNV-OS-J101 and DNV-OS-J103), or wind tunnel tests, as a setpoint to be applied to the model with a dynamically controlled feedback to the winch system (load-control-loop system see Fig. 5).

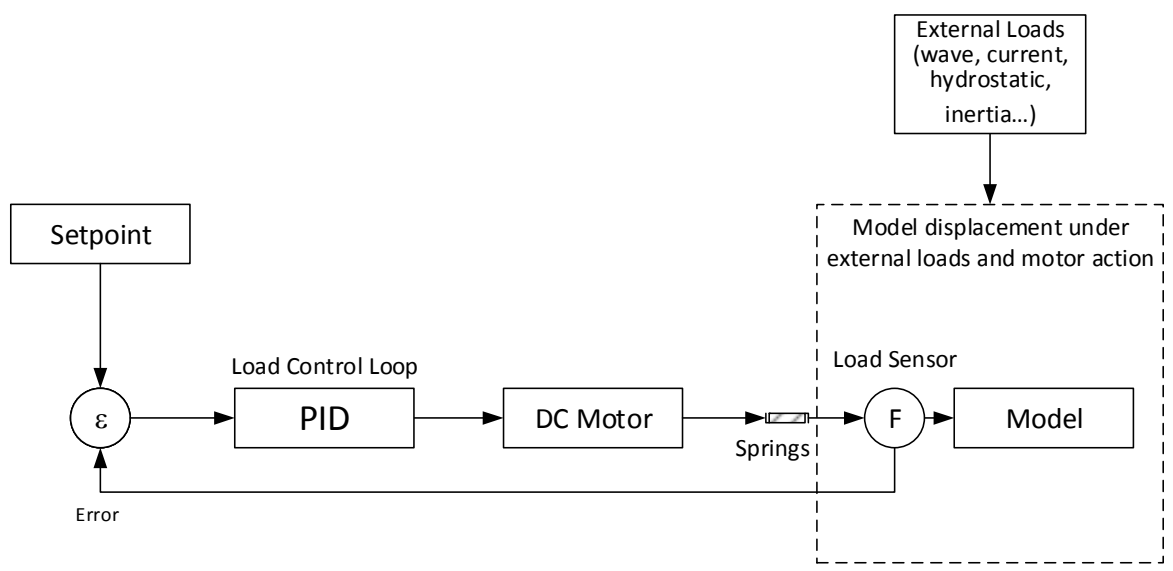

Figure 5. Wind Load Simulator (Concept).

The "wind simulator" consisted of a dynamic winch connected to the nacelle with a line of nylon and springs, a 1D load sensor to measure the load applied on the model, and a control-loop system to apply the prescribed "wind load" on the model independently of the motions of the model (Fig. 6). 


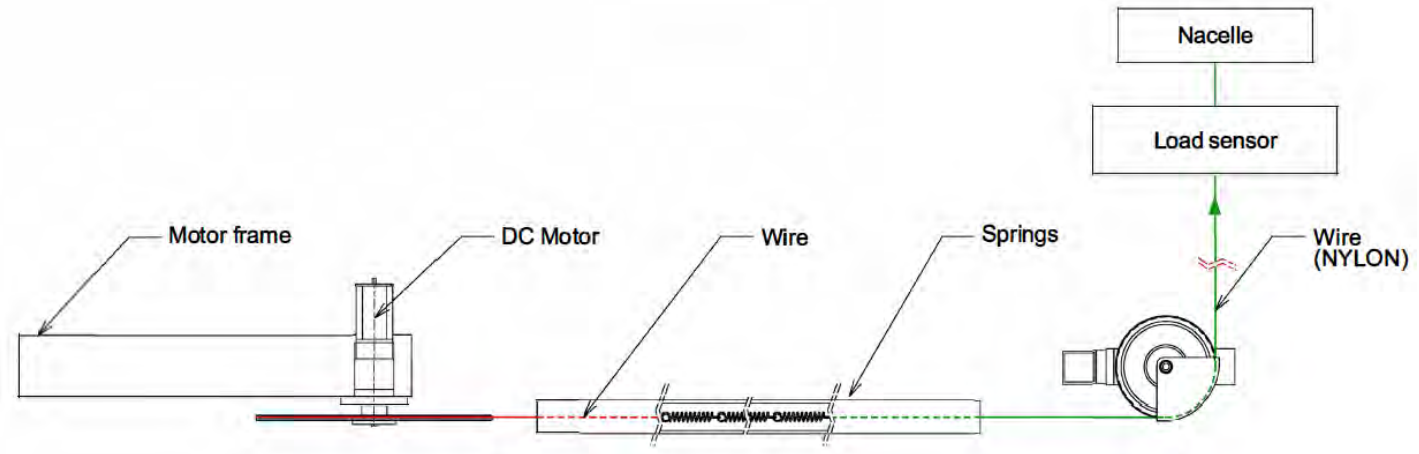

Figure 6. Wind Load Simulator (Physical modelling).

Thus, no wind was blown on the model for the present tests campaign, even if the OCEANIDE basin has the capability to do so, but an equivalent load was applied to the nacelle in order to represent the wind loadings. However, the blades have been modelled with appropriate scale and mass properties in order to investigate the influence of the gyroscopic effect and of the aerodynamic damping when the blades were rotating.

\subsection{Instrumentation}

Four categories of instrumentation have been used for the model tests: measure of environment, measure of loads, measure of motions and video observation.

The measurement of environment effects was performed with wave probes (resistive type) and a current meter (propeller type), at the exact model location for the calibration and to the side of the model for the tests with model in place. The environment conditions were calibrated without the model in the basin, and re-applied during the tests with the model in place.

The load at the foundation level was measured at the base articulation joint with 3D load sensors (Fig. 7).

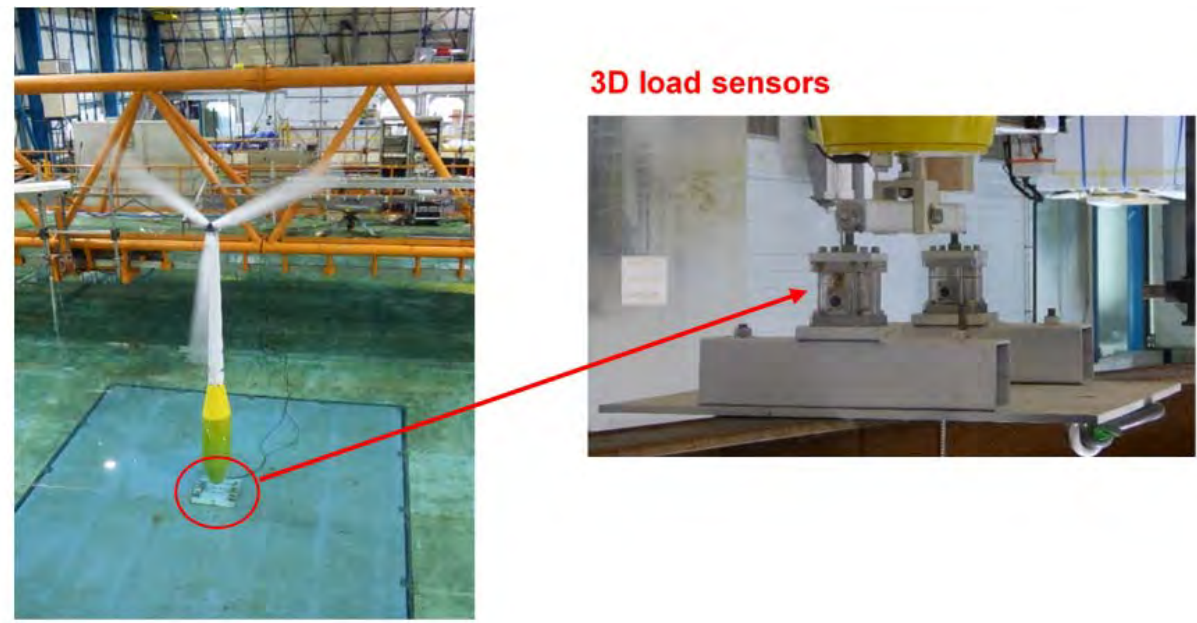

Figure 7. Load measurement at foundation. 


\section{XIV èmes Journées Nationales Génie Côtier - Génie Civil \\ Toulon, 29 juin au $1^{\text {er }}$ juillet 2016}

The wind load measured at the nacelle with a 1D load sensor (Fig. 8) is used by the wind load simulator to control the wind load applied on the nacelle to ensure that it is similar to the prescribed setpoint.

AWC pitch and roll motions were measured throughout all of the tests with a contactless tracking system measuring the position of a marker fixed to the model.

The rotor velocity was also measured.

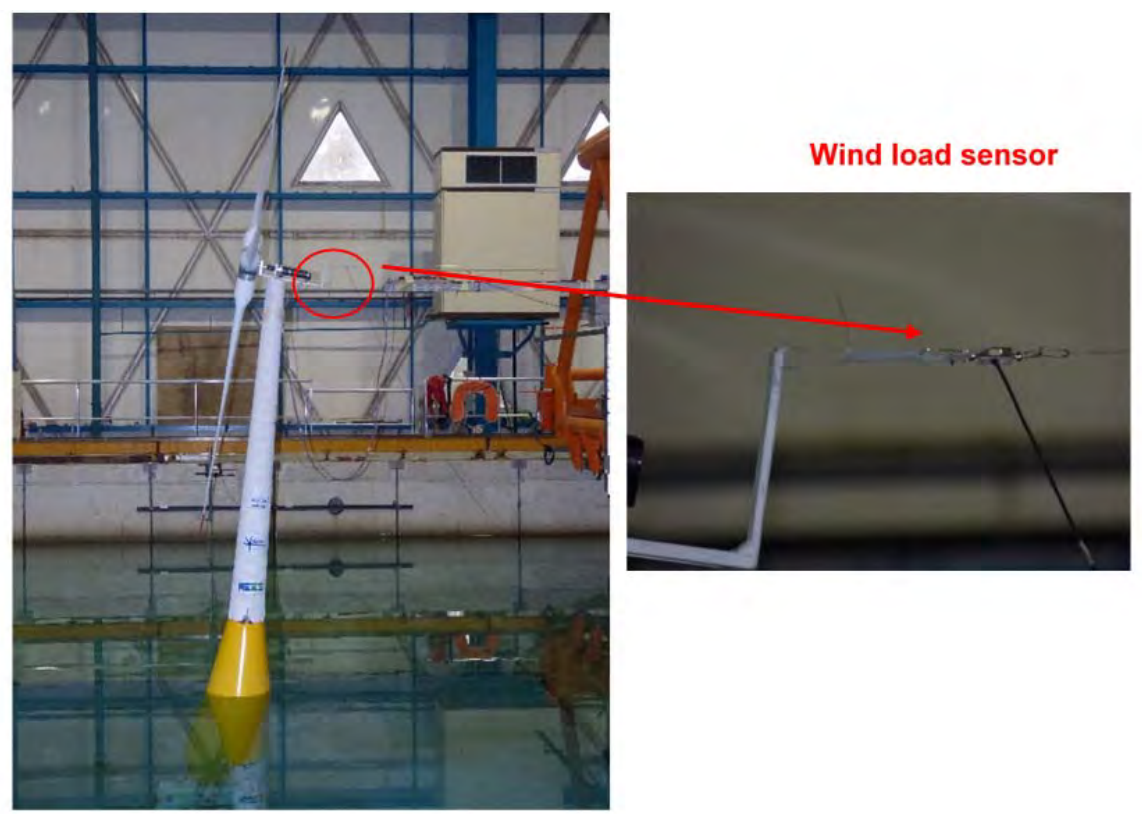

Figure 8. Wind load measurement at nacelle.

\subsection{Results}

Extensive tests were performed to check that the model complied with the specifications.

The relative difference between measured and specified values was only $1.5 \%$ for the mass, $0.2 \%$ for the buoyancy, $1.3 \%$ for the CoG elevation and less than $0.3 \%$ for the inertias.

The damping due to friction in the articulated joint was measured in air with the aid of a swinging test and found very low ( $0.3 \%$ and $1.2 \%$ of the critical damping).

Decay tests were performed to determine the natural frequency in roll (36.75s) and pitch (36.66s) of the model in water, which is very close to the theoretical natural periods (see next section).

The tower natural frequency had also been measured with the aid of a hammer test and was found high enough (i.e. much larger than the wave frequencies) not to disturb the results.

The deviation between specified and measured current speed was less than $1 \%$. 


\section{Thème 5 - Énergies et ressources marines}

The wave spectra (Fig. 9) were in good agreement with the specification, i.e. within a deviation of less than $1 \%$ on $\mathrm{Tp}$ and $5 \%$ on $\mathrm{Hs}$ and with a good match in the full wave frequency range, except for a few cases for which wave/current interaction and/or wave breaking induced a loss of energy in the spectrum tail (i.e. in the high frequencies). This could have been corrected by amplifying the wave maker command at these frequencies. However, it had been decided not to do this because this effect may be found at sea, as this mainly results from physical effects, and because the numerical model is a time domain which allows the use of the exact measured wave time series as an input.

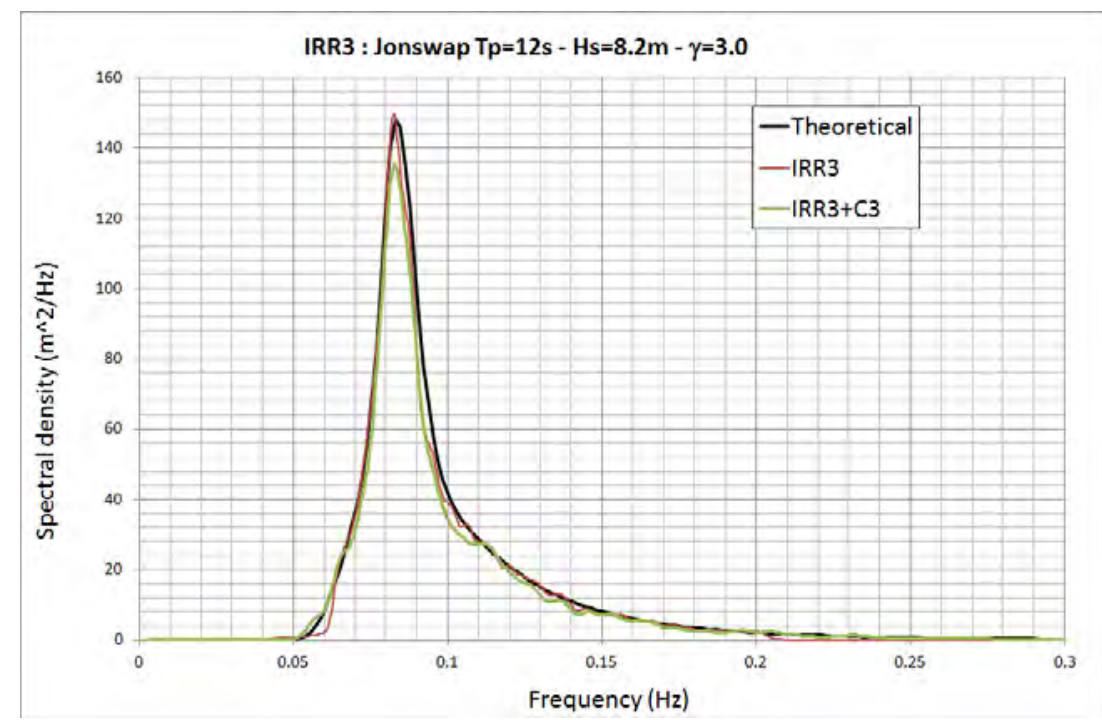

Figure 9. Comparisons between specified and measured wave spectrum.

After a phase of development and qualification, especially for the calibration of the PID (Proportional-Integral-Derivative) controller parameters, the dynamic winch used to apply the actual wind load time series to the model at the nacelle was shown to have a very good behaviour. The applied load was very close to the target one (set-point), whatever the motions of the model.

The wind loads measured in the basin match with the specification with a maximum deviation of $5 \%$ on average value, maximum value and standard deviation (Fig. 10). 


\section{XIV èmes Journées Nationales Génie Côtier - Génie Civil \\ Toulon, 29 juin au $1^{\text {er }}$ juillet 2016}

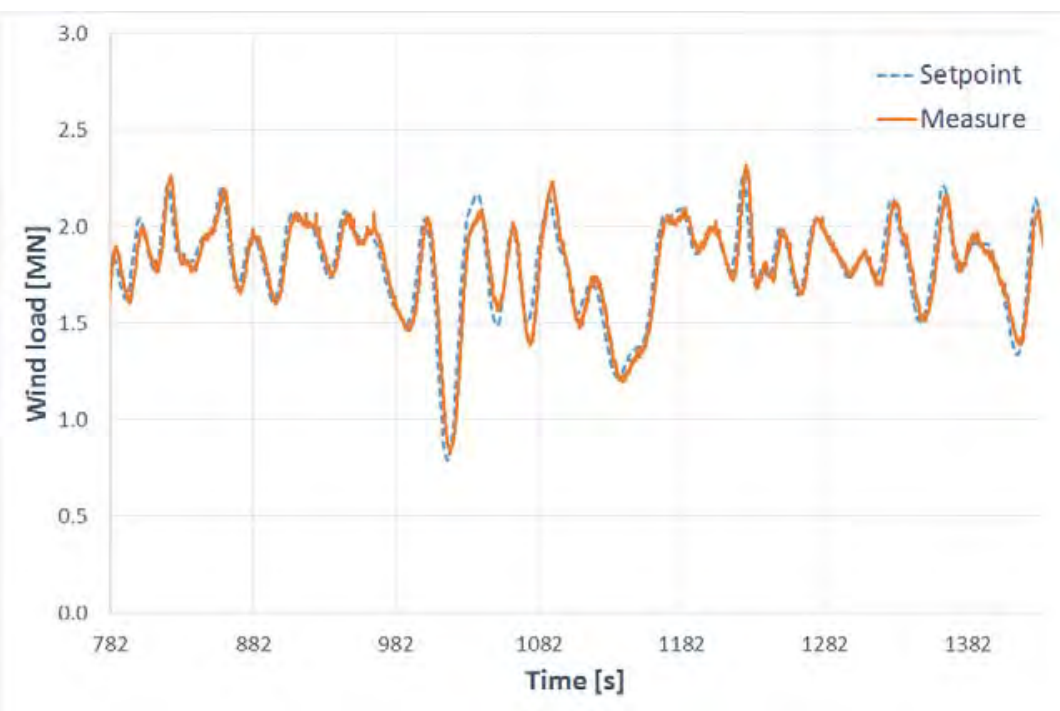

Figure 10. Comparisons between theoretical wind load and measured one.

\section{Numerical computations}

In order to study the AWC concept, a set of numerical tools had been developed by DORIS to assess the behaviour of the articulated column under environmental loads. The equation of motion for this model is:

$\left(M+M_{\text {rad }}+M_{\text {aero }}\right) \cdot \ddot{\boldsymbol{\xi}}+\left(B_{\text {rad }}+B_{\text {aero }}\right) \cdot \dot{\boldsymbol{\xi}}+K_{h} \cdot \boldsymbol{\xi}=\boldsymbol{F}_{\text {ext }}$

Where $\ddot{\xi}$ is the acceleration vector, $\dot{\xi}$ is the velocity vector, $\xi$ is the motion vector, $M$ is the mass matrix, $M_{\text {rad }}$ is the added mass matrix associated with hydrodynamic radiation, $M_{\text {aero }}$ is the added mass matrix associated with aerodynamic radiation, $B_{\text {rad }}$ is the damping associated with hydrodynamic radiation, $K_{h}$ is the hydrostatic restoring matrix, $B_{\text {aero }}$ is the linearized damping factor calibrated from experimentation and associated to the pitch velocity of the rotating part of the turbine, $\boldsymbol{F}_{\text {ext }}$ accounts for external loads applied to the AWC including wave loads (Froude-Krylov/diffraction), current loads, wind loads and reaction loads at the articulation joint.

\subsection{Numerical Model}

The modelled system consisted of a set of cylindrical elements with physical properties (diameter, specific gravity, Young modulus, drag coefficient) interconnected by nodes. The system is divided into 19 elements (12 for the column and 7 for the mast turbine). The nacelle and the rotor of the turbine were modelled by a point mass located at the top of the mast. Figure 11 shows the modelled system. 


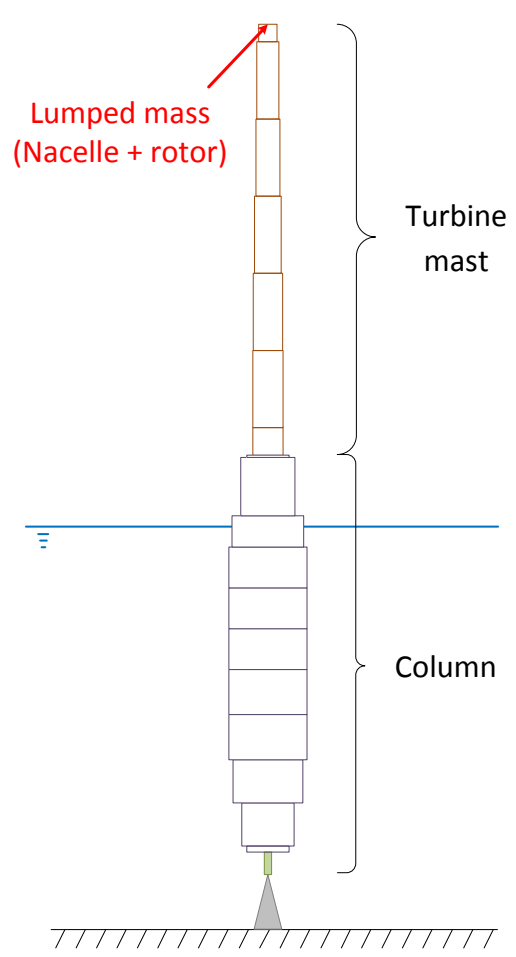

Figure 11. Numerical model.

All the nodes of the model were able to freely move in the 6 degrees of freedom except that corresponding to the articulated joint which only allowed roll and pitch motions. This structural model of the AWC was used to assess the natural periods, mode shapes and participation factors of the structure that were subsequently used to calculate the dynamic response of the system subjected to wave, wind and current loads. This modal analysis was performed by using DORIS in-house software.

The calculated natural period for the pitch/roll motion was 37.1s (considering an added mass coefficient $C_{A}=1$ ). This value was in accordance with that derived from experimentation presented in section 3 .

Considering the large dimension of the AWC, the incident wave was significantly modified by the structure and a simple Morison approach (ref. DNV-RP-C205) could not be considered to assess the wave loads on the AWC $\left(K_{C}<3.6\right)$. So added masses, damping coefficients and wave excitation loads (Froude-Krylov and diffraction, see ref. DNV-RP-C205) were calculated for each period using diffraction/radiation software. The calculated hydrodynamic database was then used as input to assess the AWC response to wave loads.

The mesh used for diffraction/radiation analysis was in accordance to the actual geometry of the submerged part of the column, as shown in Figure 12.

Wind loads on the system were modelled by a time series of applied loads to the top of the turbine mast (at hub level). The wind force was calculated by the following formula: 


\section{XIV èmes Journées Nationales Génie Côtier - Génie Civil \\ Toulon, 29 juin au $1^{\text {er }}$ juillet 2016}

$F_{\text {wind }}=\frac{1}{2} \cdot \rho_{\text {air }} \cdot C_{T}(U) \cdot S \cdot U^{2}$

Where:

$-S$ is the swept area,

$-C_{T}$ the propulsion coefficient,

- $U$ the wind speed at a given time.

Wind speed time histories have been generated based on a Kaimal spectrum (Ref DNVOS-J101).

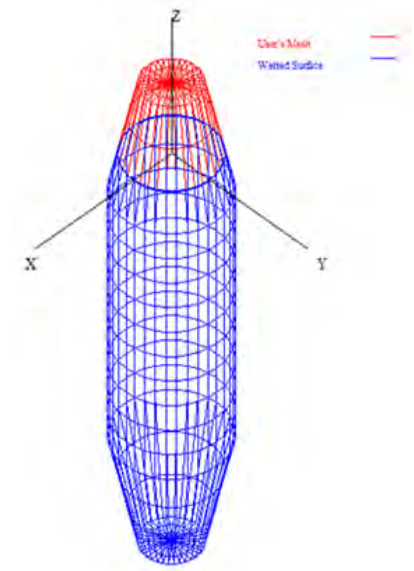

Figure 12. Mesh of the column.

\subsection{Calibration}

When the rotor was operating, experimentation highlighted that pitch motion was significantly damped. The Figure 13 provides the pitch time series obtained during decay test performed with and without rotor working.

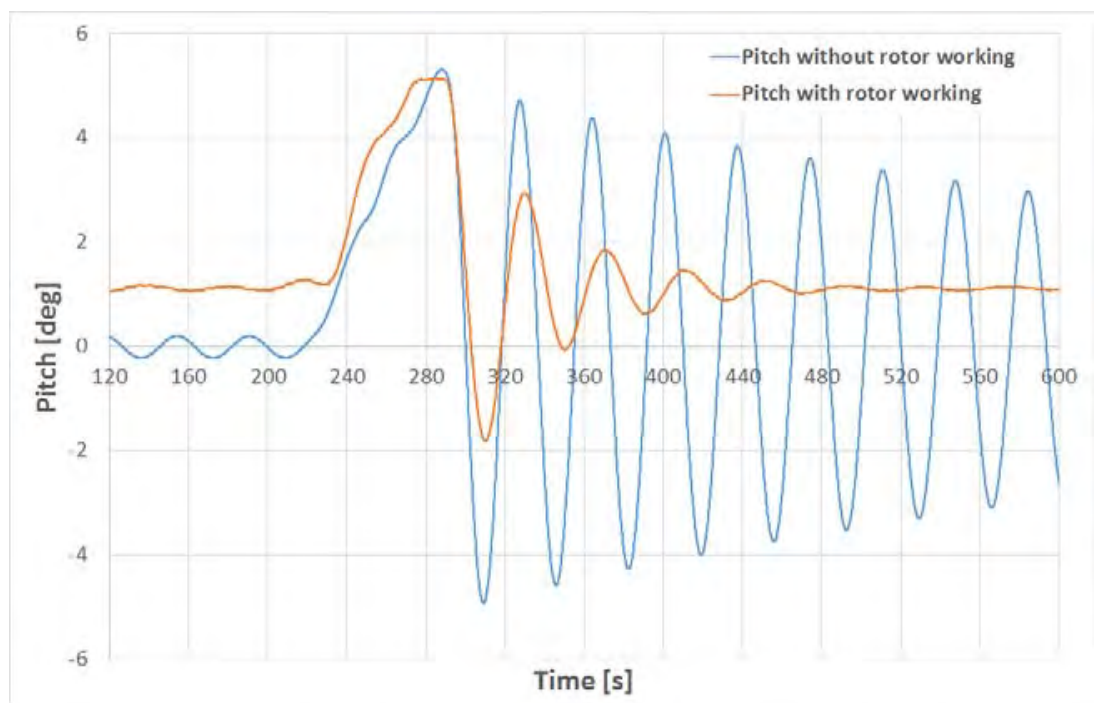

Figure 13. Experimental pitch decay tests. 


\section{Thème 5 - Énergies et ressources marines}

Based on the oscillating periods and on the attenuation of the signals presented in Figure 13, the terms $M_{\text {rad }}, M_{a e r o}, B_{\text {rad }}$ and $B_{\text {aero }}$ from equation (1) were calibrated for the model of the model. In the basin, the aerodynamic added mass matrix and damping terms were equivalent to those of a solid disc centred at the hub location, with a radius equivalent to 2/3 of blade length. The solid disc added mass and drag coefficient used were obtained from literature ( $2 / \pi$ and 1.9 respectively). It is to be remembered that blades are not corrected for Reynolds' effect. Therefore, this factor ("2/3 of the blade length") would not be exactly the same at prototype scale.

The amplitude of the damping is directly linked to the translational speed of the rotating part (motor, hub and blades). This damping has been accounted for in the numerical model by an additional damper at hub level.

Numerical decay test with the rotor working showed a good correlation with experimentation.

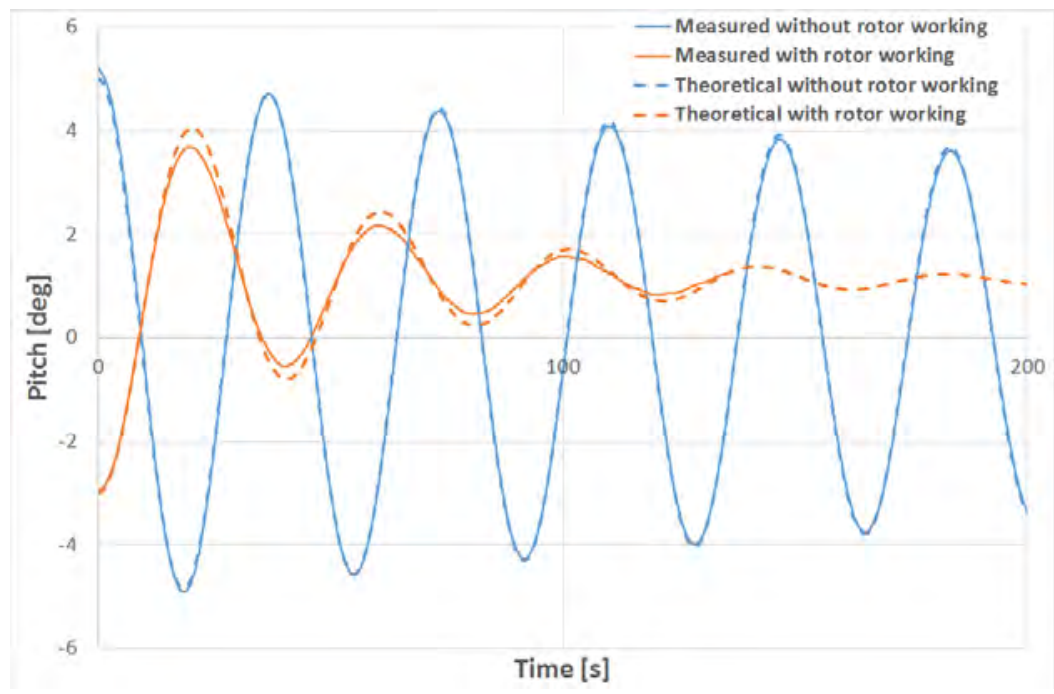

Figure 14. Experimentation/simulation comparison with the rotor working.

The aerodynamic damping coefficient, $B_{\text {aero }}$, is found to be more than 10 times higher than the hydrodynamic one $\left(B_{\text {rad }}\right)$ in the basin. Again, it is to be remembered that blades are not corrected for scale effects. Therefore, the final factor $B_{a e r o} / B_{\text {rad }}$ would not be exactly the same as for a prototype but at least, the effects or tendency would be the same. At full scale, the aerodynamic damping and the wind load can be replaced in equation (2) by the term detailed in equation (3) using the propulsion coefficient given by the wind turbine manufacturer and that will:

- Be a scale 1 value, different to the basin one value due to Reynolds' effect,

- Be dependent on the wind velocity, the pitch of the blades being controlled and adapted to the wind velocity

$\frac{1}{2} \rho_{\text {air }} C_{T}(U) S H .|H \dot{\theta}-U| \cdot(H \dot{\theta}-U)$ 


\section{XIV èmes Journées Nationales Génie Côtier - Génie Civil \\ Toulon, 29 juin au $1^{\text {er }}$ juillet 2016}

Where:

$-S$ is the swept area,

- $C_{T}(U)$ the propulsion coefficient,

- $U$ the wind speed,

- $H$ the hub height with reference to the articulated joint

$-\dot{\theta}$ the pitch angular velocity of the column

When applying the same wind time series and wave spectrum as during basin tests:

- a variation of maximum tilt of the column up to $+/-2.2 \%$ has been observed under operating environment.

- a variation of maximum tilt of the column up to $+/-4.8 \%$ has been observed under extreme environment (50 year return period).

The dynamic response of the Articulated Wind Column numerically calculated shows a good similarity with the behaviour observed during the basin model tests.

\subsection{Results}

Further to the basin tests, the calibrated numerical model has been used to validate the sizing of the column in $90 \mathrm{~m}$ water depth.

Under both operating and extreme conditions, the tilt of the column is very much governed by wind conditions.

Actually, there is very little response of the column to wave and current loads. On the other side, the column is highly sensitive to wind at low frequencies, in particular at the eigen period of the system.

Maximum inclinations of the Articulated Wind Column under operating conditions are provided in the following table:

Table 1. Maximum tilt for operating conditions.

\begin{tabular}{ll}
\hline Environmental conditions & Maximum Tilt \\
\hline Current & $0.92^{\circ}$ \\
Wave & $0.17^{\circ}$ \\
Wind & $6.32^{\circ}$ \\
Wind + wave + current & $6.55^{\circ}$ \\
\hline
\end{tabular}

In addition, a tilt non-exceedance probability curve has been calculated based on operating environment distribution (Fig. 15). 


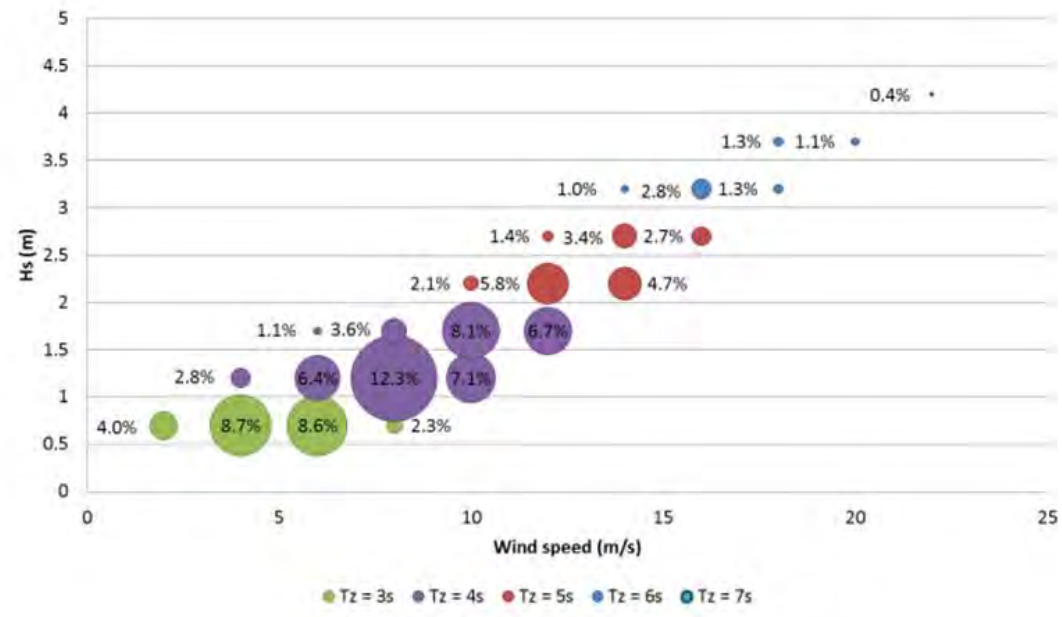

Figure 15. Environment distribution.

Tilt distribution for operating conditions shows that a tilt of more than $4^{\circ}$ does not occur more than $2 \%$ of the time.

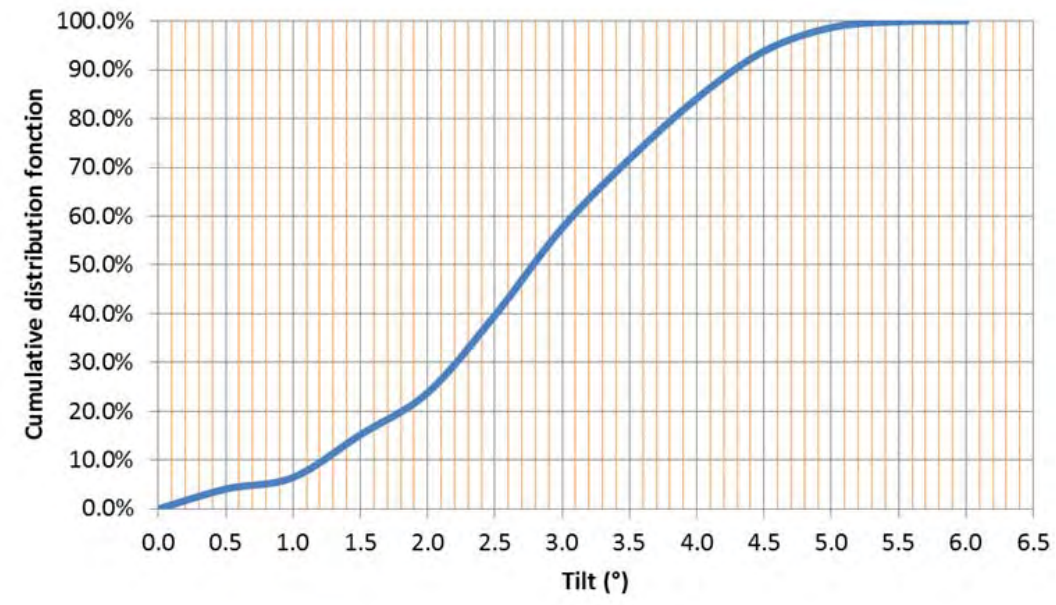

Figure 16. Tilt no-exceedance probability.

Figure 16 shows the suitable performance of the concept of the articulated column for supporting a wind turbine. Under these conditions, it is possible to take advantage of the wind turbine capacity to produce electrical energy.

\section{Conclusions}

As part of this study, a numerical method to define and understand the behaviour of the articulated wind column when subjected to simultaneous wave, wind and current loads was developed. 


\section{XIV èmes Journées Nationales Génie Côtier - Génie Civil \\ Toulon, 29 juin au $1^{\text {er }}$ juillet 2016}

The basin test campaign carried out at BGO FIRST, performed by OCEANIDE, allowed DORIS to calibrate the numerical model, and to validate the design of the articulated wind column.

The validation of the numerical model is a key point in the progress of the project, as the behaviour of the column affects the sizing, and therefore the associated cost of the column. It was therefore essential to fully understand this behaviour.

The dynamic winch developed by OCEANIDE used to apply the actual wind load time series to the model at the nacelle has shown a very good behaviour. The applied load was very close to the target, whatever the motions of the model happened to be. The next stage of the development is to add a loop in the system based on the real time measurement of the model motions, in order to represent a full scale aerodynamic damping without any scale effect.

The concept developed by MEES and DORIS provides an interesting solution for offshore wind turbines in water depths up to $200 \mathrm{~m}$. It should be noted that with increasing water depth the righting moment increases quicker than the overturning moment due to wind. Because of this effect, the performance and efficiency of the AWC concept is better in deeper water, which would allow reductions in size or column diameter.

The next stage of the project consists in finding partners (turbine manufacturers, wind farm developers, fabricators) to make a prototype/demonstration at full scale.

\section{Acknowledgements}

The authors gratefully acknowledge the support from the UK Department of Energy and Climate Change who partly funded the study work.

\section{References}

DNV-OS-J101 (2014). Design of Offshore Wind Turbine Structures. Det Norske Veritas AS, 238 p. URL : http://rules.dnvgl.com/docs/pdf/DNV/codes/docs/2014-05/Os-J101.pdf DNV-OS-J103 (2013). Design of Floating Wind Turbine Structures. Det Norske Veritas AS, 124 p. URL : http://rules.dnvgl.com/docs/pdf/DNV/codes/docs/2013-06/OS-J103.pdf DNV-RP-C205 (2014). Environmental Conditions and Environmental Loads. Det Norske Veritas AS, 182 p. URL : http://rules.dnvgl.com/docs/pdf/DNV/codes/docs/2014-04/RP-C205.pdf MOLIN B., REMY F., FACON G. (2002) Etude expérimentale du comportement Hydro-Aéro-Elastique d'une éolienne offshore sur ancrages tendus. Sea Tech Week 2002, Brest.

LANGEART O., BROCHERIE J., DAVIES R., BROUGHTON P. (2015) Concept de colonne articulée comme support d'éolienne offshore. ATMA.

URL : http://www.atma.asso.fr/FR/publication_detail.php?pub=686\&page=18 
Thème 5 - Énergies et ressources marines 